MET Rennes

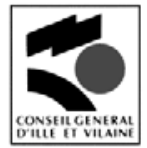

a㑢

We gratefully acknowledge all these institutions and companies for their financial or material support

armoróeines

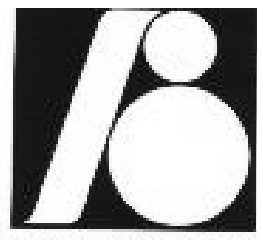

BONGRAINSA
A

BRAN LUEBBE

A United Dominion Company
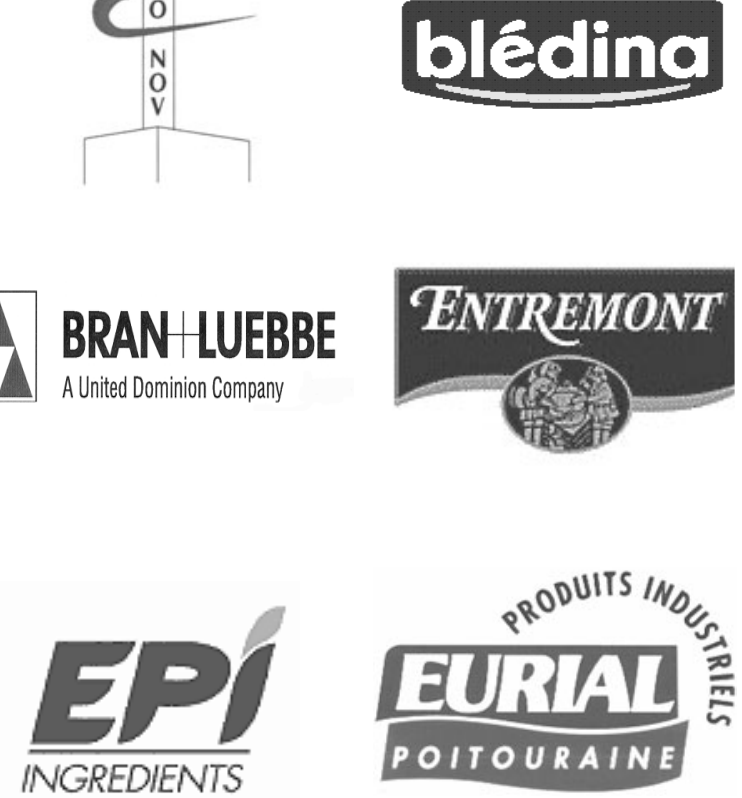

eurosérum

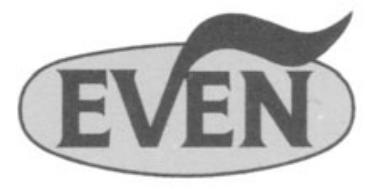



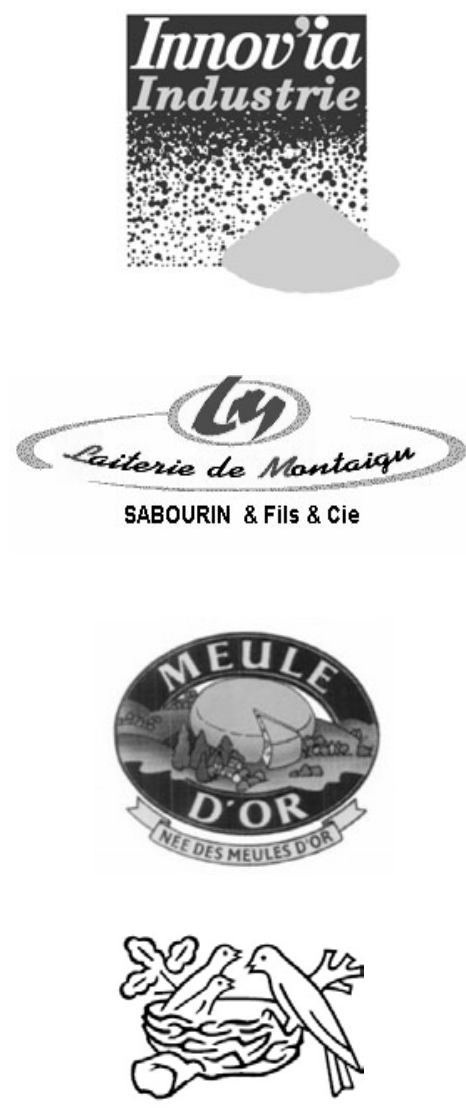

Nestle

\section{(2) paysan}

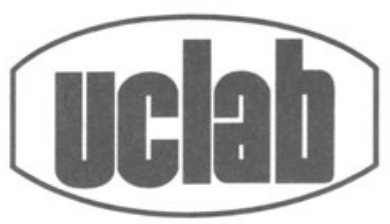

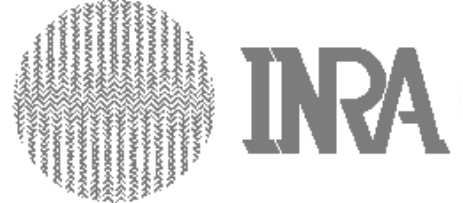

\section{LACTALIS}

Institut National de la Recherche Agronomique
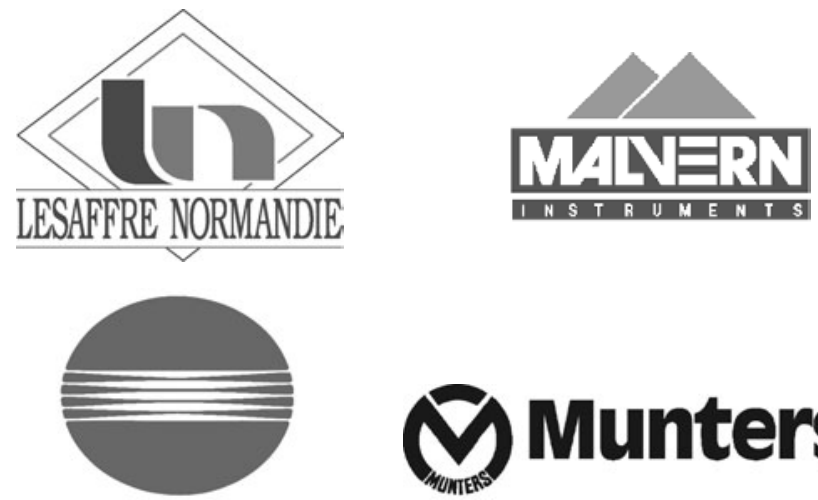

MINOLTA
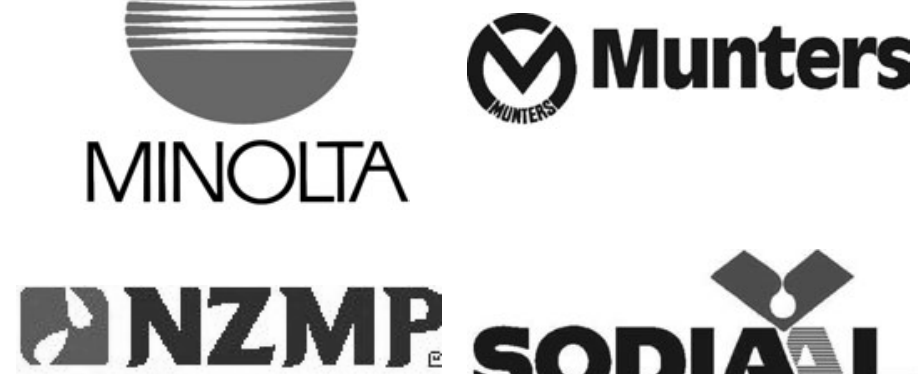

Now Zealand, making th happent
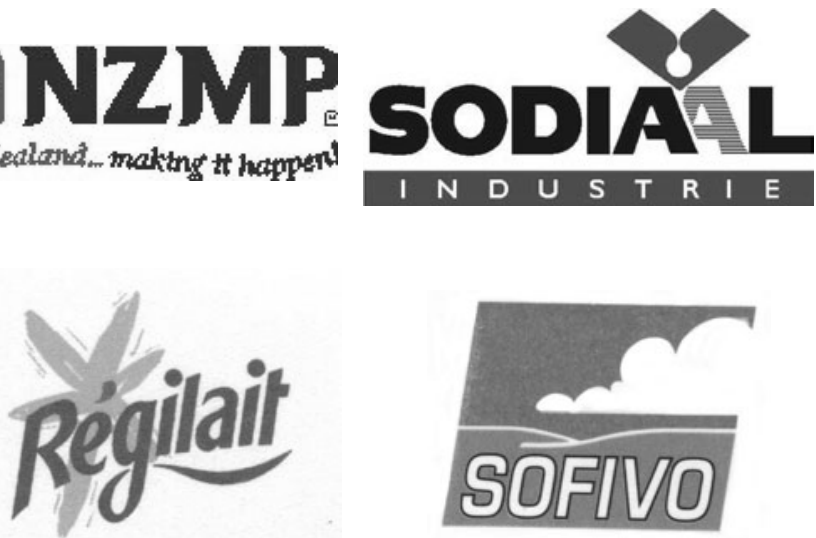

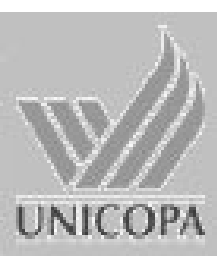

